積層ゴムで支持した塔状免震建物の終局挙動に関する振動台実験

\title{
SHAKING TABLE TESTS ON ULTIMATE BEHAVIOR OF SLENDER BASE-ISOLATED BUILDINGS SUPPORTED BY LAMINATED RUBBER BEARINGS
}

高 岡栄治*1, 二村有 則*1, 飯 塚真巨*2, 竹中 康 雄*3, 吉川和 秀*4

Eiji TAKAOKA, Arinori NIMURA, Masao IIZUKA,

Yasuo TAKENAKA and Kazuhide YOSHIKAWA

\begin{abstract}
This paper describes results of shaking table tests on ultimate behavior of high aspect ratio base-isolated buildings. In the tests, a base-isolated structure model weighing $192 \mathrm{kN}$ supported by 4 laminated rubber bearings was used. The aspect ratio of superstructure ( 4 or 6 ), and shape and axial stress of a laminated rubber bearing were set for experimental parameter. The results of tests indicate that the ultimate behavior of base-isolated buildings are roughly classified into two types; one is caused by buckling fracture of rubber bearings and the other is caused by tensile fracture of rubber bearings. These types are dependent on relationship between lateral restoring characteristics of base-isolated story and static ultimate lateral force by uplift of superstructure.
\end{abstract}

Keywords : base-isolated building, laminated rubber bearing, aspect ratio, ultimate behavior, shaking table test 免震建物、積層ゴム、塔状比、終局挙動、振動台実験

\section{1.はじめに}

兵庫県南部地震以降、積層ゴムを用いた免震構造はその有効性が 認知され、広く普及するところとなった。従来免震構造が適用対象 とされてきた建物は、塔状比（建物の高さと幅の比）の比較的小さ い中低層建物が中心であった。しかし、近年ではその適用が高層建 物へも及び、塔状比が 3 を超えるような事例も多く見受けられる。

一般に、塔状比が大きくなると建物には大きな転倒モーメントが生 じる。よって、地震時にはロッキング振動が生じやすく、隅角部の 積層ゴムには大きな変動軸力が生じる。さらに設計レベルを超える 地震動が入力された場合、積層ゴムには引張力あるいは過大な圧縮 力が生じ、建物は不安定な状態へ、また最悪の場合積首ゴムの破壊 により終局的な状態へと至ることも予想される。このような終局举 動を把握することは、免震建物の安全余裕度の定量的な評価に有益 であるのみならず、今後予想されるさらなる高塔状化に対する設計 資料ともなり得る重要な課題である。

免震構造の終局挙動に関する研究は、主として免震部材単体の終 局挙動を把握することに重点が置かれてきた。積層ゴムについては、 圧縮、引張り、せん断の各特性に関する実駼結果より限界性能に関 する考察が行われ、終局挙動が概ね明らかにされている 12)。一方、 免震建物の性能を確認するためには、模型等による振動台実験が有 効である。終局挙動の把握を目的として、積層ゴムが破断するまで の振動台実験も数多く実施されているが、主に塔状比の小さい原子
炬建屋を対象としたものである ${ }^{3)}$ 。また、塔状比の大きい試験体を 用いて大入力に対する挙動を確認する実験も実施されている。猿田 等は高減衰積層ゴムと塔状比 6.2 の試験体を用いた実験を 4 )、久野 等は弾性滑り支承と積層ゴムを組み合わせた構法と塔状比 5 の試験 体を用いた実験を実施し5)、それぞれ既往地震波 $100 \mathrm{~cm} / \mathrm{s}$ 相当の入 力時に積首ゴムに引張りが生じるが、その後の挙動に大きな影響を 与えないことを確認している。また、三山等は積層ゴムとオイルダ ンパーを組み合わせた構法と塔状比 5 の試験体を用いた実験より、 振動台実験の積層ゴム特性が理論値と対応することを確認した他、 引張りが生じた後の着座による最大軸力が予測できることを示した 6)。しかし、これまで塔状比の大きい建物を対象とし、積層ゴムの 破壤までの終局挙動の把握を目的とした研究は行わ扎ていない。ま た、積層ゴムの形状や塔状比など終局挙動に影響を与える要因をパ ラメトリックに报った研究も見られない。

以上の背景の下、積層ゴムで支持した塔状免震建物の終局挙動を 解明することを目的として、縮小免震建物模型を用いた振動台実験 を実施した。実験要因として、建物上部構造の塔状比、積層ゴムの 形状・面圧を採用し、水平 1 方向入力により積層ゴムが破壊に至る まで加振した。実験結果より、終局時における上部構造と積層ゴム の詳細な挙動について分析し、各要因が終局挙動に与える影響につ いて検討した。
本論文の一部は文献12)～17)にて発表している。

*1 鹿島技術研究所 主任研究員 · 修士 (工学)

*2 鹿島技術研究所 上席研究員 · 修士 (工学)

*3 鹿島小堀研究室 室次長・修士 (工学)

*4 鹿島 ITソリューション部 グループ主事
Senior Research Engineer, Kajima Technical Research Institute, Kajima Corp., M. Eng.

Supervisory Research Engineer, Kajima Technical Research Institute, Kajima Corp., M. Eng.

Assistant Director, Kobori Research Complex, Kajima Corp., M. Eng. Senior Coordinator, Intelligent Systems Department, Kajima Corp. 


\section{2. 実験要因と水準の設定}

終局挙動に影響を与える要因として、上部構造の塔状比 $\mathrm{H} / \mathrm{B}(\mathrm{H}$ : 建物高さ、B : 積層ゴムの軸芯間距離)、積層ゴムの形状・面圧を選 定した。塔状比は 4 及び 6 の 2 つの水準を設定した。積層ゴムの形 状は、後述の想定構造物における原型の大きさで設定し、ゴム総厚 $\mathrm{h}$ を共通の $200 \mathrm{~mm}$ 、直径 D を $800 \mathrm{~mm}$ 及び $1000 \mathrm{~mm}$ とした。2 次 形状係数 $\left(\mathrm{S}_{2}=\mathrm{D} / \mathrm{h}\right)$ はそれぞれ 4 及び 5 である。想定構造物におけ る面圧 $\sigma$ （鈶直荷重/積層ゴム断面積）はそれぞれ $7.90 \mathrm{MPa}$ 及び $5.05 \mathrm{MPa}$ であり、前者では形状・面圧を相対的に小径・高面圧とす ることで水平力低下型の復元力特性が、後者では大径・低面圧とす ることでハードニング型の復元力特性が現れることを想定している。 積層ゴムは鈶プラグ入り積層ゴム（LRB）とした。以上を組み合わ せた実験ケースを表 1 に示す。実験ケースは計 4 ケースである。

\section{3. 試験体}

想定構造物における原型として、直径 D が $800 \mathrm{~mm}$ 又は $1000 \mathrm{~mm}$ の積層ゴム 4 体で支持した総重量 $15880 \mathrm{kN}$ の剛な塔状免震建物を 想定した。試験体は、表 2 に示す相似則に従って原型を $1 / 9$ に縮尺 した縮小模型である。試験体の形状・寸法を図 1 に示す。

\section{1 上部構造}

上部構造は、鉄筋コンクリート製の重鏵 4 個を PC 鋼棒で締結し たものである。全体寸法は、短辺 $1,300 \mathrm{~mm} \times$ 長辺 $1,600 \mathrm{~mm} \times$ 高さ $4,000 \mathrm{~mm}$ である。短辺方向の積層ゴム軸芯間距離 $\mathrm{B}$ は、塔状比 4 で $1,000 \mathrm{~mm}$ 、塔状比 6 で $680 \mathrm{~mm}$ とした。上部構造の総重量 W の 測定值は $192 \mathrm{kN}$ である。以下ではこの上部構造を「重鍾」と呼ぶ。

\section{2 㮴凪ゴム}

模型積層ゴムの形状諸元を表 3 に、材料の物性規格を表 4 に示す。 積層ゴムは鈶プラグ入り積層ゴムであり、ゴム総厚 $\mathrm{h}$ が全ケース共 通で $22 \mathrm{~mm}$ 、直径 D が $90 \mathrm{~mm}$ 及び $110 \mathrm{~mm}$ 、面圧 $\sigma$ が $7.55 \mathrm{MPa}$ 及 び $5.05 \mathrm{MPa}$ である。表 5 に、これらの積層ゴムを用いた場合の試 験体全体の力学特性設計值を示す。免震周期は 1.33 秒及び 1.09 秒 で、原型に換算すると 4 秒及び 3.3 秒程度である。また、鈶プラグ の降伏せん断力係数は 0.0441 及び 0.0659 である。積層ゴムは、水 平及び鉛直の 2 方向荷重計（分力計）とレベリング装置を介して振 動台に固定した。レベリング装置は、ボルトを回転させることによ り、各積層ゴムの支持荷重を均等にするための装置である。

\section{4. 実験方法}

\section{1 加振方法}

入力地震動は $\mathrm{BCJ}-\mathrm{L} 2$ 波 7)を用いた。加速度の最大值は $356 \mathrm{~cm} / \mathrm{s}^{2}$ であり、10 秒までの長周期域で高く安定したパワーを持つ。これを 相似則に従い時間軸を $1 / 3$ に縮小した。入力方向は短辺水平 1 方向 とした。加振レベルは、原波を基準として 0.5 倍、 1.0 倍…と 0.5 倍刻みで、積層ゴムが破壊するまで振幅を增幅させた。以下では加 振レベルを「倍率 $\times \mathrm{L} 2$ 2」と表記する。また、図 2 に、ケース(1)の加 振レベル $2.5 \times \mathrm{L} 2$ の時の、振動台上での加速度測定波と縮小原波の 擬似速度応答スペクトルを比較して示す。これより、3 秒以上の周 期領域で測定波のパワーが低下しているが、3 秒以下ではほとんど 一致しており、試験体の免震周期近傍でのスペクトル特性を忠実に 再現できている。

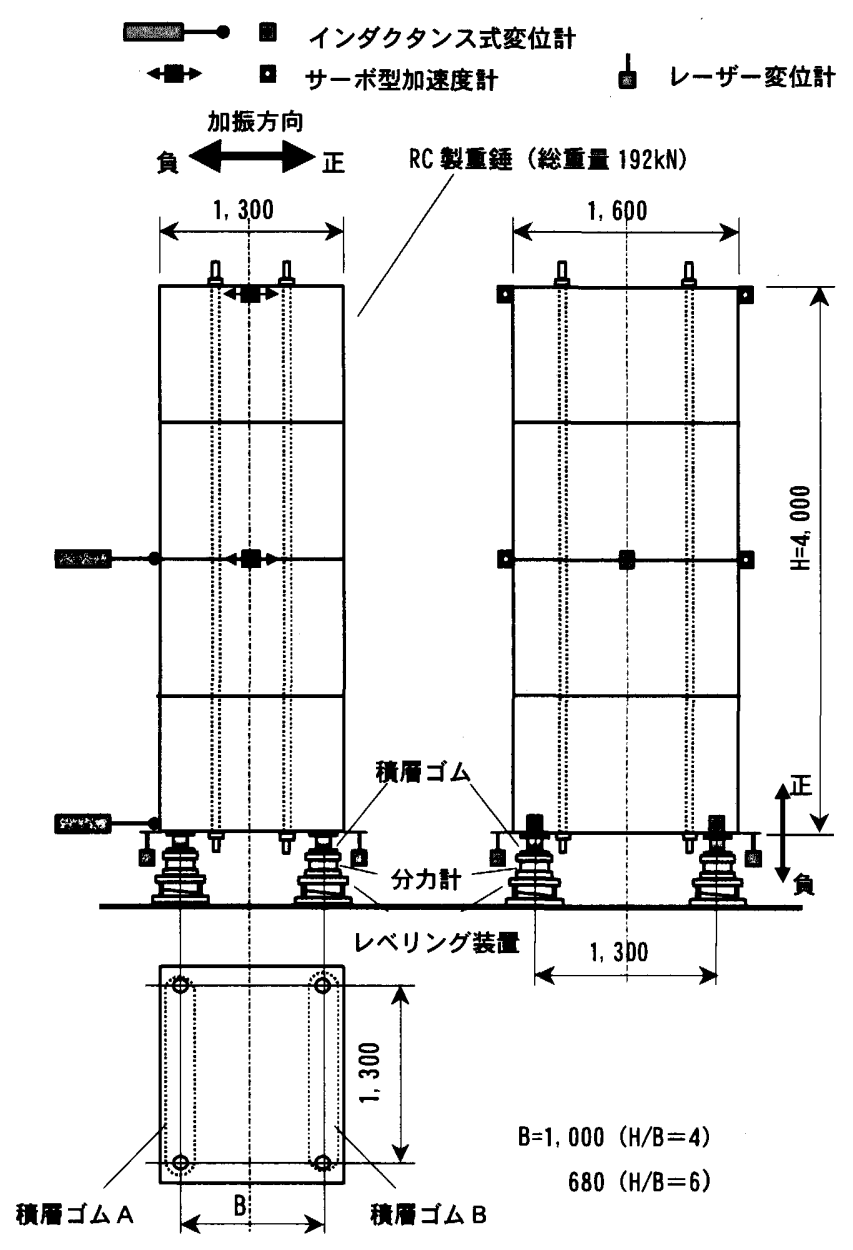

図 1 試験体の形状・寸法、変位計・加速度計の設置

表 1 実験ケース

\begin{tabular}{|c|c|c|c|}
\hline & \multicolumn{2}{|c|}{ 塔状比 $(\mathrm{H} / \mathrm{B})$} \\
\hline & & 4 & 6 \\
\hline \multirow{2}{*}{$\begin{array}{l}\text { 原型積層ゴム } \\
\text { 形状・面压 } \\
(\mathrm{h}=200 \mathrm{~mm})\end{array}$} & $\begin{array}{c}\mathrm{D}=800 \mathrm{~mm} 、 \mathrm{~S}_{2}=4 \\
\sigma=7.90 \mathrm{MPa}\end{array}$ & ケース(1) & ケース(3) \\
\hline & $\mathrm{D}=1000 \mathrm{~mm}, \mathrm{~S}_{2}=5$ & ケーース(2) & ケース(4) \\
\hline
\end{tabular}

表 2 相似則 $(\lambda=9)$

\begin{tabular}{|c|c|c|c|}
\hline 項目 & (模型) $/$ (原型) & 項目 & (模型) $/$ (原型) \\
\hline 時間 (周期) & $1 / \sqrt{\lambda}$ & 力 (重量) & $1 / \lambda^{2}$ \\
\hline 加速度 & 1 & 剛性 & $1 / \lambda$ \\
\hline 速度 & $1 / \sqrt{\lambda}$ & 忍力度 & 1 \\
\hline 変位 (長さ) & $1 / \lambda$ & ひずみ度 & 1 \\
\hline
\end{tabular}

表 3 模型積層ゴムの形状諸元

\begin{tabular}{|lc||c|c|}
\hline \multicolumn{2}{|c|}{ 実験ケース } & (1)、(3) & (2)、(4) \\
\hline 直径 D(外径) & $(\mathrm{mm})$ & 90 & 110 \\
\hline 内径 (钻径) & $(\mathrm{mm})$ & 18 & 22 \\
\hline 1 層コ厚 & $(\mathrm{mm})$ & \multicolumn{2}{|c|}{1.0} \\
\hline ゴム総厚 $\mathrm{h}$ & $(\mathrm{mm})$ & \multicolumn{2}{|c|}{22} \\
\hline 中間鋼板厚 & $(\mathrm{mm})$ & \multicolumn{2}{|c|}{1} \\
\hline 1 次形状係数 S1 & 22.5 & 27.5 \\
\hline 2 次形状保数 $\mathrm{S} 2$ & 4.1 & 5.0 \\
\hline 支持重量 & $(\mathrm{kN})$ & \multicolumn{3}{|c|}{48.0} \\
\hline 静止時面压 & $(\mathrm{MPa})$ & 7.55 & 5.05 \\
\hline
\end{tabular}




\section{2 測定方法}

重錘について、上端と重心の水平加速度をサーボ型加速度計で、 重心と下端の水平変位をインダクタンス式変位計で、下端四隅の鈶 直変位をレーザー変位計でそれぞれ測定した。加速度計と変位計の 設置位置を図 1 に示す。積層ゴムの水平変形は重鍾下端の水平変位 で代用し、積層ゴムの鈶直変形は、重鍾四隅の鉛直変位を積層ゴム 位置の変位に換算して求めた。積層ゴムの水平荷重と鉛直荷重は積 層ゴムに直結した分力計によって測定した。水平方向の極性は入力 波の符号と対応させ、鈶直方向は上方を正にした。積層ゴムに作用 する鈶直荷重については、引張りを正、压縮を負とし、重鍾重量分 を差し引いて荷重がかかっていない状態が原点となるように後で補 正した。測定サンプリングは $200 \mathrm{~Hz}$ とした。

\section{5. 実験結果}

一連の加振シリーズを通して、㨝れ振動や加振と直交方向の振動 はわずかであり、積層ゴムの個体差もほとんど認められなかった。 よって、正側の 2 つの積層ゴム同士あるいは負側の 2 つの積層ゴム 同土はほとんど同一の荷重・変形挙動を示した。そこで以後、負側 の 2 つをまとめて「積層ゴム $\mathrm{A}$ 、正側をまとめて「積層ゴム $\mathrm{B} 」 と$ 呼ぶことにする（図 1 平面図参照)。そして、積層ゴムA（あるい

表 4 材料の物性規格

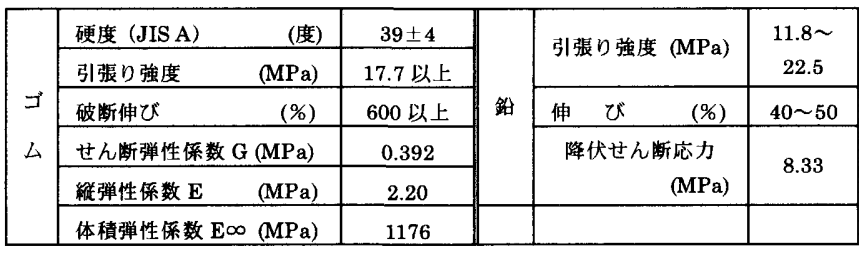

表 5 試験体の力学特性（設計値）

\begin{tabular}{|c|c|c|c|c|}
\hline 実験ケース & (1) & (2) & (3) & (4) \\
\hline 免震周期 (s) & 1.33 & 1.09 & 1.33 & 1.09 \\
\hline 水平剛性 $($ 䄼膡ゴム 4 体 $)\left(\times 10^{5} \mathrm{~N} / \mathrm{m}\right)$ & 4.35 & 6.51 & 4.35 & 6.51 \\
\hline 鈶直固有振動数 $(\mathrm{Hz})$ & 32.3 & 42.2 & 32.3 & 42.2 \\
\hline 鈶直剛性(樍層ゴム 4 体) $\left(\times 10^{5} \mathrm{~N} / \mathrm{m}\right)$ & 8052 & 13770 & 8052 & 13770 \\
\hline 鈶プラグの降伏せん断力倸数 & 0.0441 & 0.0659 & 0.0441 & 0.0659 \\
\hline
\end{tabular}

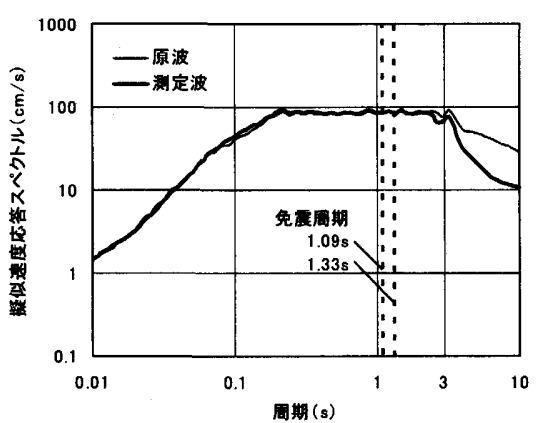

図 2 擬似速度応答スペクトル（ケース(1)、2.5×L2）

表 6 積層ゴム破壊時加振レベルと破壊形式

\begin{tabular}{|c|c|c|c|c|}
\hline ケース & (1) & (2) & (3) & (4) \\
\hline 加㨡レベル & $3.0 \times \mathrm{L} 2$ & $4.5 \times \mathrm{L} 2$ & $3.0 \times \mathrm{L} 2$ & $4.0 \times \mathrm{L} 2$ \\
\hline 樍首コム & 座屈 & - & 座屈 & - \\
\hline 積首コム & - & 引張り破断 & - & 引張り破断 \\
\hline
\end{tabular}

はB）の荷重及び変形として、負側（あるいは正側）の 2 つの積層 コムの荷重の和及び変形の平均値を求めた。以下に実験結果を項目 に分けて詳述する。

\section{1 积展ゴム破壊時加振レベルと破壊形式}

いずれのケースについても、加振レベルの増大に伴い積層ゴムに 過大な水平変形や引張り変形又は沈み込み変形が生じ、積層ゴムの 破壊により終局に至った。表 6 に、積層ゴム破壊時における加振レ ベルと積層ゴムの破壊形式を示す。また、各ケースの破壊状況を以 下に記す。

ケース(1)：水平変形が直径相当の変形を超え重鉷全体が沈み込み、

積層ゴム $\mathrm{A}$ が座屈破壊し、その直後に積層ゴム $\mathrm{B}$ も座屈破壊した。 ケース(2)：水平変形が直径にほぼ相当する変形に達したが、重鍾が 浮き上がり、積層ゴム $\mathrm{B}$ が引張り破断した。

ヶース(3):積層ゴム B には引張り変形が生じたが、水平変形が直径 に相当する変形を超えて重鍾の積層ゴム $\mathrm{A}$ 側が沈み込み、積層ゴム A が座屈破壊した。

ケース(4)：水平変形は直径相当の変形で留まるが、重錘が頻繁に浮 き上がり、両方の積層ゴムに引張り変形が生じた。最後は積層ゴム Bが引張り破断した。

\section{2 大入力時の連動パターン}

時刻歴波形によって大入力時における重錘の運動パターンを調ベ た。図 3 に、大変形が生じた加振レベル $2.5 \times \mathrm{L} 2$ について、積層ゴ $\triangle \mathrm{A} 、 \mathrm{~B}$ の鉛直変形、重鍾重心水平変位と免震層水平変位、兔震層 回転角、重鍾重心と頂部の水平加速度、重鍾頂部の鈶直加速度、積 層ゴム $\mathrm{A} 、 \mathrm{~B}$ の鈶直荷重の時刻歴波形を示す。時刻は最も大きな変 形が生じた 15〜17 秒である。これより、以下のことが指摘できる。 ケース(1):積層ゴム A に大きな沈み込み変形が生じているが、積層 ゴム $\mathrm{B}$ にも沈み込み変形が生じている。一方、免震層水平変位と重 心水平変位の差異は僅かであり、免震層回転角も他ケースと比較し て小さい。よって、重鍾の運動は、若干下方へ沈み込みながらも概 ね並進的であることが分かる。水平加速度及び重心鉛直加速度は他 のケースと比較して稳やかな波形となっている。鈶直荷重は、積層 ゴム $\mathrm{A}$ の沈み込み変形の最大値が生じる時刻に対応して、静止時荷 重のほぼ 2 倍程度となるが、他ケースと比べて変動は小さい。 ケース(2)：積層ゴム A に僅かな沈み込み変形と、積層ゴム B に大き な引張り変形が生じている。引張り変形が生じている間、免震層水 平変位は增加せず重心水平変位よりも小さくなっている。よって、 重錘の運動は、積層ゴム $\mathrm{A}$ を支点として積層ゴム $\mathrm{B}$ 侧が浮上する回 転的な運動であることが分かる。また、頂部水平加速度及び重心鈶 直加速度には、引張り変形が収まった時刻(16s 付近)すなわち重鍾が 着地した時刻に衝撃的な加速度が生じ、その後自由振動する波形が 認められる。鉛直荷重は、引張り変形が生じている間、積層ゴム B には引張り荷重が生じるが、積層ゴム A では静止時荷重の 2 倍を超 える圧縮荷重となる。また、重錘の着地により両積層ゴムの鈶直荷 重が大きく変動し、その変動量は最大で静止時荷重の 2 倍を超える。 ケース(3): 積層ゴム A に沈み込み変形が、積層ゴム B に引張り変形 が生じているが、鉛直変位の平均値はゼロ近傍の值で推移している。 また、引張り変形が生じている間、免震層水平変位は增加せず重心 水平変位よりも小さくなっている。よって、重錘の運動は、重鍾下 端中央部を支点とした回転的な運動であることが分かる。着地時に 

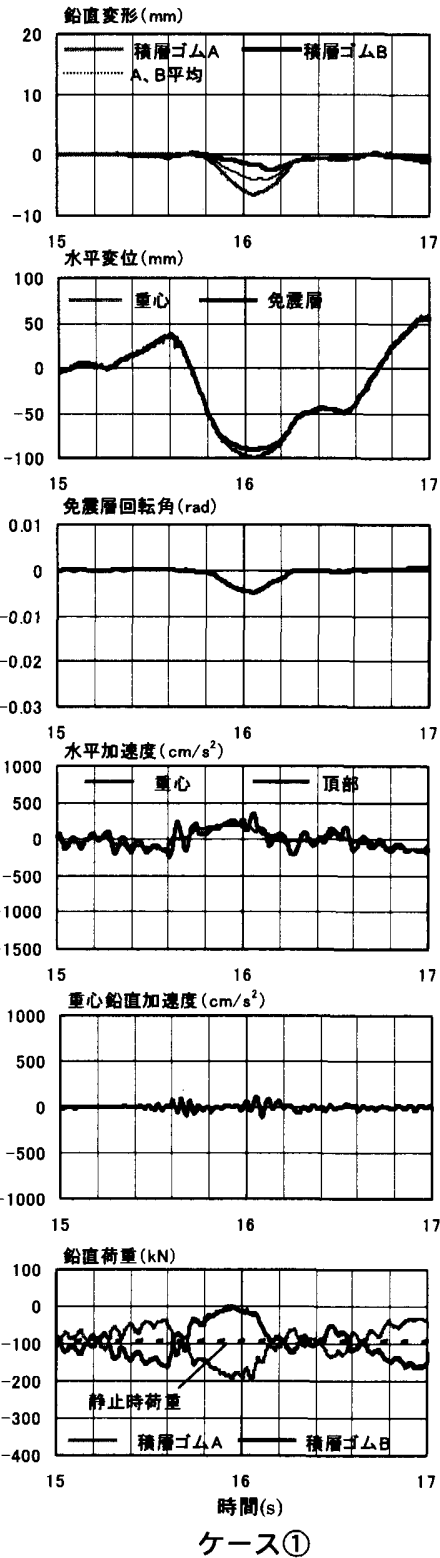

哈直变形 $(\mathrm{mm})$
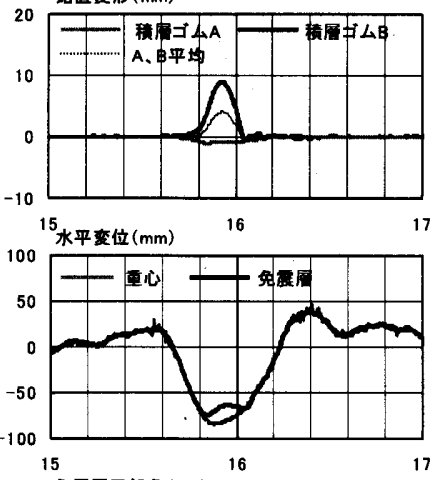

免霞屏回枟角( $\mathrm{rad})$
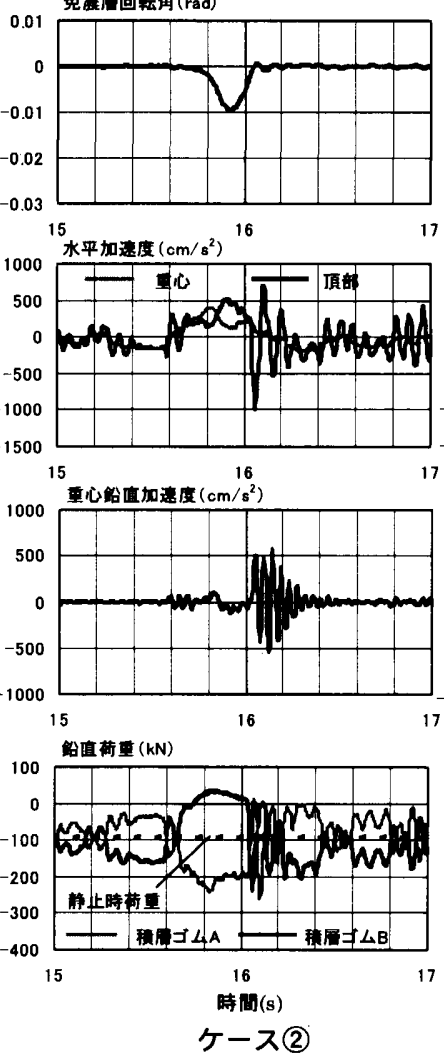

鉛直麦形 $(\mathrm{mm})$
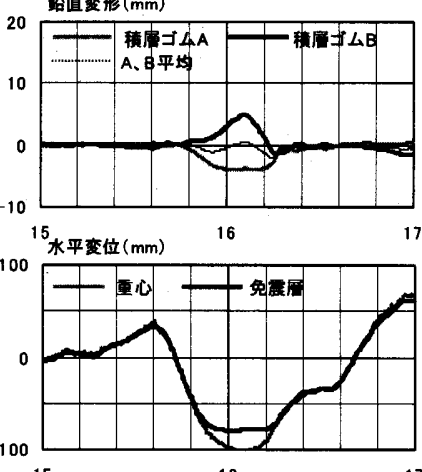

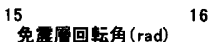
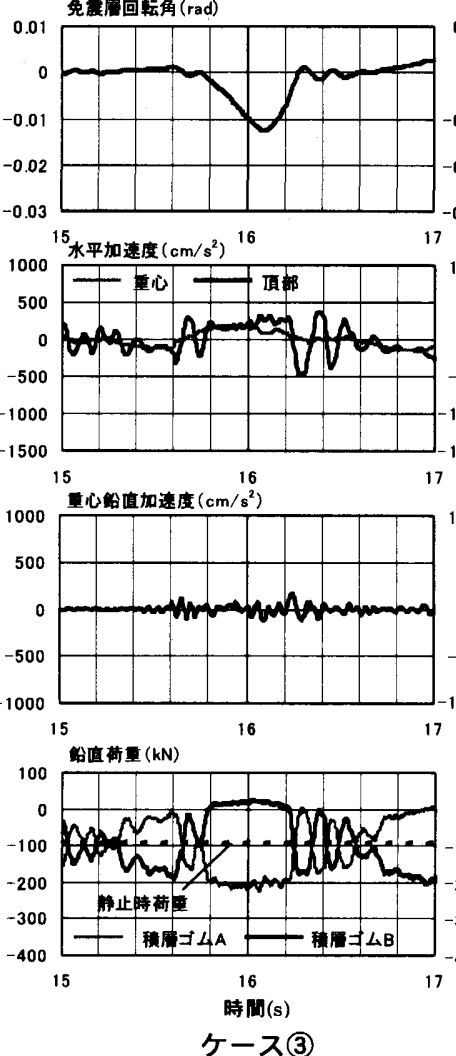

ケース(3)
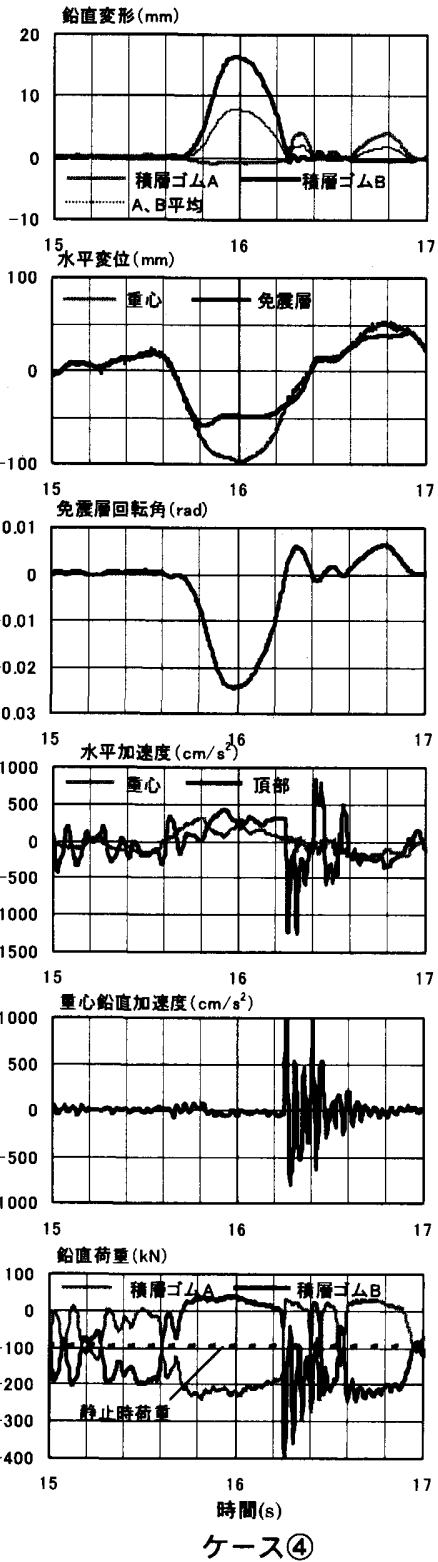

図 3 時刻歴波形の比較 $(2.5 \times \mathrm{L} 2)$

頂部水平加速度及び重心鈶直加速度がやや大きくなっているが、ケ 一ス(2)、(4)と比べれば小さい。鈶直荷重の性状はケース(2)とほぼ同 様である。

ケース(4):積層ゴム $\mathrm{A}$ に僅かな沈み込み変形と、積層ゴム $\mathrm{B}$ に大き な引張り変形が生じている。他ケースと比較すると最も大きな引張 り変形及び免震層回転角が生じている。重錘の運動はケース(2)と同 じく積首ゴム $\mathrm{A}$ を支点として積層ゴム $\mathrm{B}$ 側が浮上する回転的な運動 であるが、積層ゴム $\mathrm{B}$ 側での着地と同時に積層ゴム $\mathrm{A}$ に引張り変形 が生じており、回転的な運動が連続して現れている。このため、頂 部水平加速度及び重心鉛直加速度には、重鍾の着地に伴う衝撃的な 加速度が数回認められる。また、重錘の着地により、最大で静止時 荷重の 4 倍に相当する鉛直荷重が生じている。

以上より、大入力時における重鍾の運動パターンは、積層ゴムの 沈み込み変形によって重錘全体が沈み込んだケース(1)の沈み込み型、 積層ゴムの引張り変形によって重錘が回転し浮き上がったケース(2)、 (4)の浮き上がり型、積層ゴムの沈み込み変形と浮き上がり変形が同
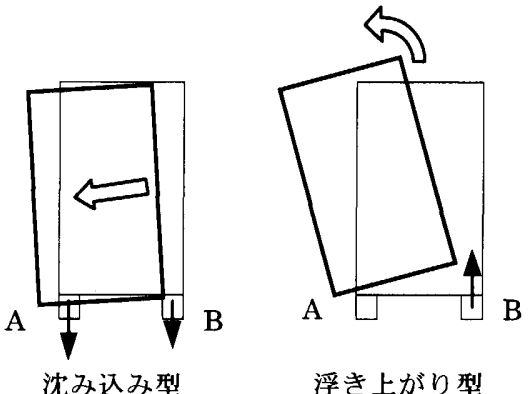

浮き上がり型

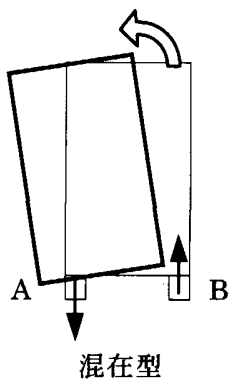

図 4 重鍾の運動状態の概略

時に生じたケース(3)の混在型に分類することができる。図 4 に運動 パターンの概略を示す。

\section{3 大入力時の運動パターンを支配する要因}

前記の 3 つの運動パターンを決定づける要因として、免震層の水 平復元力特性と剛体の静的浮き上がり限界水平力に着目した。前者 は実験要因である積層ゴムの形状・面圧に、また、これから述べる ように後者は塔状比に関連している。剛体の静的浮き上がり限界水 
平力とは、水平面上に置いた剛な直方体の重心に水平力を静的に作 用させ、直方体が圧縮端を回転中心にして浮き上がり始めた瞬間の 水平力である。モーメントの釣り合いから、剛体の静的浮き上がり 限界水平力 $Q_{u p}$ は次式で定義される。

$$
\mathrm{Qup}_{\mathrm{up}}=\mathrm{W} /(\mathrm{H} / \mathrm{B})
$$

ここで、 $\mathrm{W}$ は直方体の重量である。図 5 に、各ケースの免震層水平 力 $(\mathrm{Q})$-水平変形 $(\delta \mathrm{h})$ 曲線を示す。加振レベルは $2.5 \times \mathrm{L} 2$ であ り、図中には Qup 示している。これらの図より、以下のことが指 摘できる。

沈み込夕型 (ケース(1)：最大水平変形は $91 \mathrm{~mm}$ であり、積層ゴム 直径 $90 \mathrm{~mm}$ に対して $100 \%$ を超えている。また、 $\mathrm{Q}-\delta \mathrm{h}$ 曲線は最 大変形時に頭打ちとなり、水平力は常に Qup 以下である。

混在型 (ケース(3)：最大水平変形は $80 \mathrm{~mm}$ であり、積層ゴム直径 $90 \mathrm{~mm}$ に対して $90 \%$ 程度に達している。このケースの $\mathrm{Q}-\delta \mathrm{h}$ 曲線 はケース(1)とほぼ同様であるが、H/B が 6 のため Qup がケース(1)よ りも小さくなり、水平力が $\mathrm{Qup}_{\mathrm{u}}$ を上回っている。なお、時刻歴波形 によると、水平力が $\mathrm{Q}_{\mathrm{up}}$ を超えた時刻が浮き上がり開始時刻にほぼ 対応していた。

浮き上がり型 (ケース(2)、(4)) : ケース(1)、(3)と比較して水平剛性と 水平力の最大值が大きくなっているのは、ケース(2)、(4)の方が積層 ゴム直径が大きく、面圧も低いためである。最大水平変形はそれぞ れ 74mm、60mm であり、積層ゴム直径 $110 \mathrm{~mm}$ に対してそれぞれ $67 \%$ 及び $55 \%$ に抑えられている。両ケース共に水平力が $Q_{\text {up }}$ を上回 っている部分が認められる。H/Bが 4 のケース(2)では、水平力に八 一ドニングが生じており、水平力が $\mathrm{Q}_{\mathrm{up}}$ を大き超えている。一方、 ケース(4)では、水平力の最大值はケース(2)よりも小さいが、 H/B が 6 のため $\mathrm{Q}_{\mathrm{up}}$ がケース(2)よりも小さい。このため、最大変形時だけ でなく、-30mm 付近、さらに正側変形時など、水平力が頻繁に $\mathrm{Qup}_{\mathrm{up}}$ を超えている。また、時刻歴波形によれば、両ケース共にケース(3) と同様、水平力が $\mathrm{Qup}_{\mathrm{up}}$ 超えた時刻が浮き上がりの開始時刻にほぼ 対応していた。以上より、積層ゴムの引張り変形の生起は、 $Q_{u p}$ と $\mathrm{Q}$ の大小関係に支配されており、沈み込み変形の生起は免震層水平
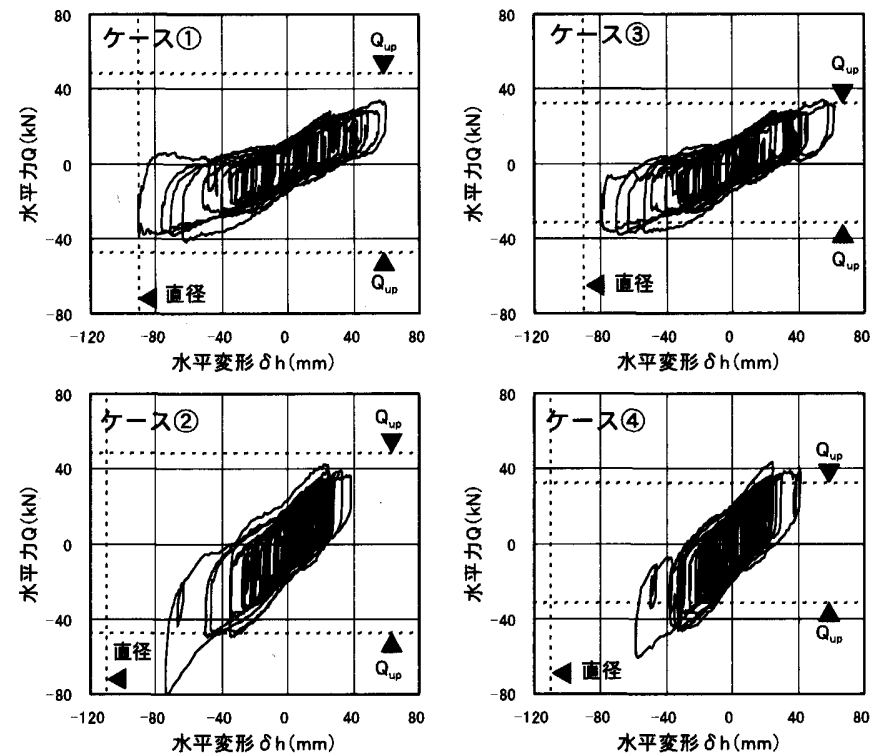

図 5 免震層水平力 $(\mathrm{Q})$ - 水平変形 $(\delta \mathrm{h})$ 曲線 $(2.5 \times \mathrm{L} 2)$
変形の直径に対する割合に関係することが分かる。よって、大入力 時における重錘の運動パターンは、 $\mathrm{Qup}_{\mathrm{u}}<\mathrm{Q}$ の場合には基本的に浮き

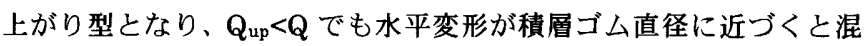
在型となる。一方、Qup $>\mathrm{Q}$ の場合には水平変形が積層ゴム直径に近 づくと沈み込み型となる。

\section{4 程層ゴムの挙動}

沈み込み型（ケース(1)）と浮き上がり型（ケース(2)）の大入力時 における積層ゴムの詳細举動を調べた。図 6、7 に、加振レベル 2.5 $\times \mathrm{L} 2$ における、各積層コ抬の水平力 $(\mathrm{Q})$ - 水平変形 $(\delta \mathrm{h})$ 曲線、 鉛直変形 $(\delta \mathrm{v})-\delta \mathrm{h}$ 曲線、鉛直荷重 $(\mathrm{P})-\delta \mathrm{h}$ 曲線、 $\mathrm{P}-\delta \mathrm{v}$ 曲 線を示す。図中の $\mathrm{a}$ 又は $\mathrm{b}$ の記号は各ループ上の同時刻の地点を表 す。これより、以下のことが指摘できる。

ケース(1)：負側の最大水平変形は $91 \mathrm{~mm}$ （せん断ひずみ $\gamma=$ 水平変 形/ゴム総厚 $=414 \%$ ) である。積層ゴムの直径は $90 \mathrm{~mm}$ であるので、 上下の端面がちょうどずれたような状況になっている。 $\mathrm{Q}-\delta \mathrm{h}$ 曲 線より、積層ゴム A では、水平変形が-60mm $(r=270 \%)$ 付近で 負勾配が発生するが、その後も水平力が最小となる点 a まで変形が 進む。よって、負勾配発生点に対して、概ね 1.5 倍程度の水平変形 能力を有していることが分かる。一方、積層ゴム B では、水平力は 若干のハードニングを伴い点 $\mathrm{a} に て$ 最大となる。 $\mathrm{Q}-\delta \mathrm{h}$ 曲線にお ける差異は、それぞれの積層ゴムに生じる鉛直荷重の違いによる。 $\mathrm{P}-\delta \mathrm{h}$ 曲線によれば、点 $\mathrm{a}$ 付近において積層ゴム A に静止時荷重 のほぼ 2 倍程度が生じているのに対し、積層ゴム B はほぼ無負荷の 状態となっている。また、 $\delta \mathrm{v}-\delta \mathrm{h}$ 曲線より、沈み込夕変形は水平 変形の增大に伴い大きくなる。鉛直荷重が大きいほど沈み込み変形 は大きくなる傾向にあり、積層ゴム A では点 aにおいて最大の沈み 込み変形 $6.6 \mathrm{~mm}$ （鈶直ひずみ $\varepsilon=$ 鉿直変形/ゴム総厚 $=30 \%$ ）が生 じている。 $\mathrm{P}-\delta \mathrm{v}$ 曲線より、積層ゴム $\mathrm{A}$ では、点 $\mathrm{a}$ に向かうルー プにおいて鉛直剛性が低下し、その後大きな履歴ループを描いてい る。一方、積層ゴム $\mathrm{B}$ では、点 $\mathrm{a}$ 前後において小さな履歴ループを 描くが、ここではループの向きは図中矢印に示す左回りである。こ のような $\mathrm{P}-\delta \mathrm{v}$ 曲線の複雑さは、鉛直沈み込みの挙動が鈶直荷重 だけでなく水平変形にも依存するためである。

本ケースでは相対的に直径の小さい積層ゴムを比較的高い面圧で 使用している。よって、直径に近い水平変形下では、積層ゴムの水 平力が水平変形だけでなく鉛直荷重にも、鉛直変形が鉛直荷重だけ でなく水平変形にもそれぞれ影響を受け、複雑な挙動を示すことが 分かる。また、これらの依存性は、定性的には既往の積層ゴム単体 の圧縮せん断試験と一致する結果となっている。一方、図 5 ケース (1)の免震層 $\mathrm{Q}-\delta \mathrm{h}$ には負勾配やハードニングは認められず、免震 層全体の復元力特性に、個々の積首ゴムの不安定な特性が与える影 響は小さいことが分かる。

ケース(2) : 負側の最大水平変形は $74 \mathrm{~mm}(\gamma=340 \%)$ である。積層 ゴムの直径は $110 \mathrm{~mm}$ であるので、水平変形は直径の $67 \%$ に相当す る。Q- $\delta \mathrm{h}$ 曲線については、両積層ゴムに大きな違いは認められ ず、概ねバイリニアで表される安定した履歴ループを描いている。 $\mathrm{P}-\delta \mathrm{h}$ 曲線によると、鉛直荷重の変動量が静止時荷重の 2 倍を超 える部分も認められるが、 $\mathrm{Q}-\delta \mathrm{h}$ 曲線にはその影響がほとんど現

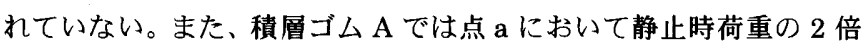
を超える鉛直荷重が生じ、積層ゴム $\mathrm{B}$ の点 $\mathrm{b}$ 付近では概ね降伏荷重 

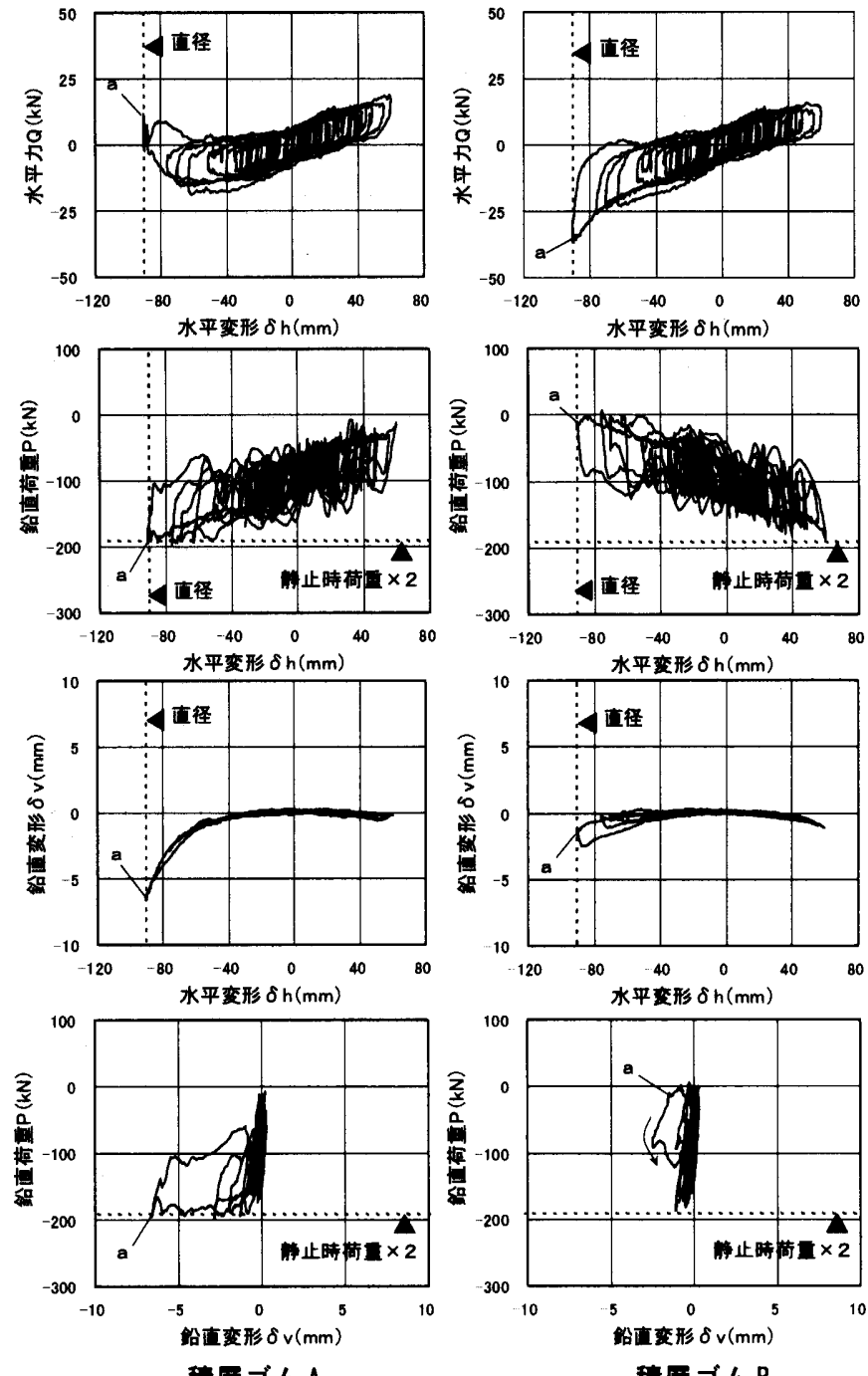

積展ゴムA

図 6 沈み込み型の履歴曲線（ケース(1)、2.5 $\times$ L2）

に達している。一方、 $\delta \mathrm{v}-\delta \mathrm{h}$ 曲線によると、鈶直変形の水平変形 依存性は小さく、鉛直荷重の変動に対応して、積層ゴム $\mathrm{A}$ の点 $\mathrm{a}$ で は $1.0 \mathrm{~mm}(\varepsilon=5 \%)$ 程度の沈み込み変形が、積層ゴム $\mathrm{B}$ の点 $\mathrm{b}$ で は $8.9 \mathrm{~mm}(\varepsilon=40 \%)$ の引張り変形が生じている。P $-\delta \mathrm{v}$ 曲線より、

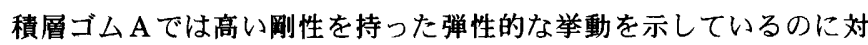
し、積首ゴム B では圧縮域から引張り降伏までは高い剛性を保ち、 引張り降伏以降は塑性流れを起こす弾塑性的な性状を示している。

本ケースでは相対的に直径の大きな積層ゴムを比較的低い面圧で 使用している。また、水平変形は積層ゴム直径の $2 / 3$ 程度の大きさ であった。このため、水平特性は鉛直荷重の比較的大きな変動に対 しても安定し、鉛直変形は水平変形の影響を受けにくい結果となっ た。すなわち、水平力は主として水平変形だけに、鉆直変形は主と して鈶直荷重だけに依存する単純な性状を示すと言える。

\section{5 終局加振レベルの評価}

本実験の結果を既往の限界特性に関する提案式と比較し、本実験 による積層ゴムの終局加振レベルを評価した。

沈み込み型のケース(1)及び混在型のケース(3)について、沈み込み 変形が生じた積首ゴム $\mathrm{A}$ に着目した。図 8 に、1.5 $\times$ L 2 以上の加振 レベルにおける最大せん断ひずみとその時の面圧 $\sigma$ をプロットした。
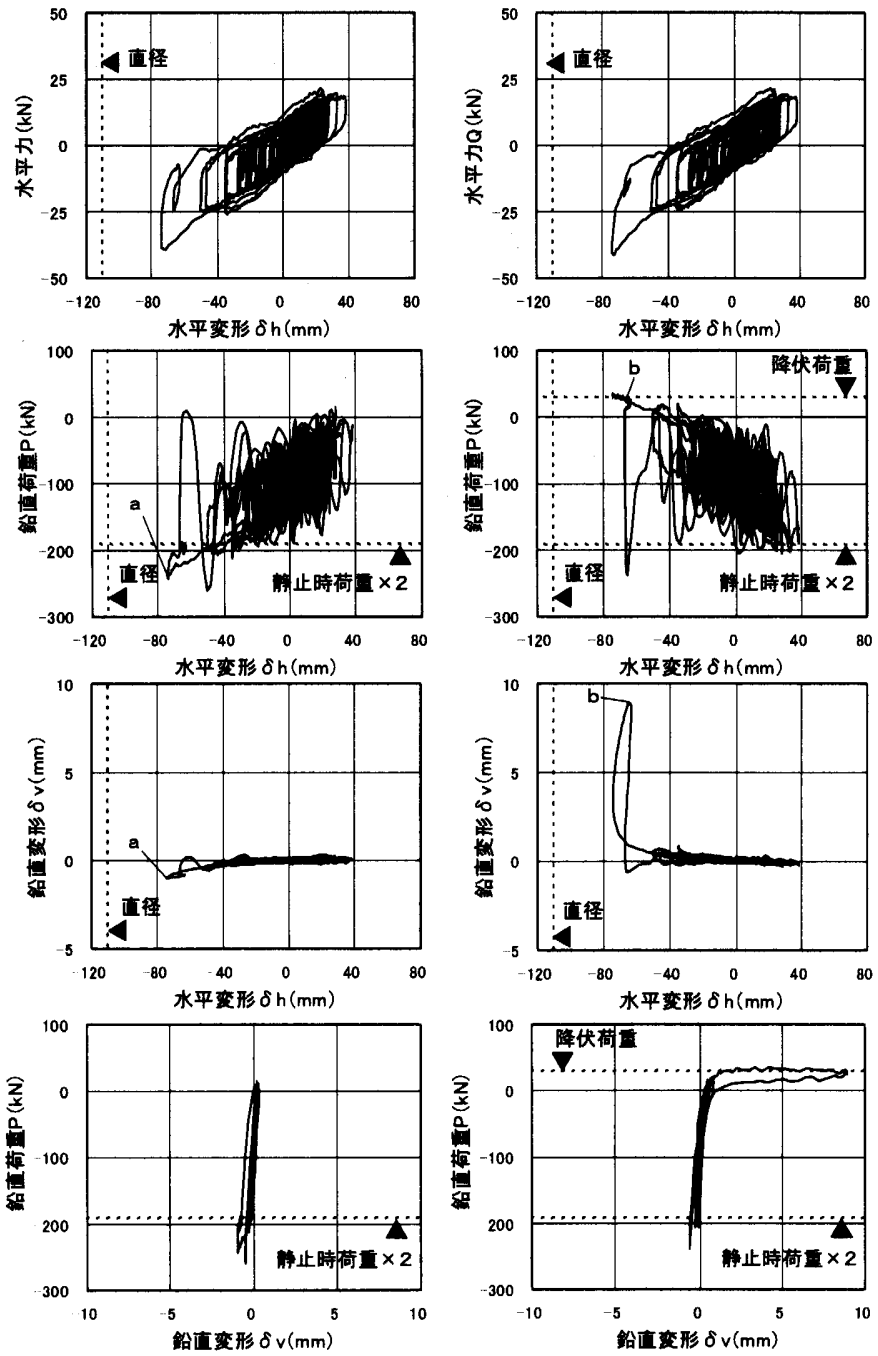

箖展コム A

程凩ゴムB

図 7 浮き上がり型の履歴曲線（ケース(2)、2.5 $\times$ L2)

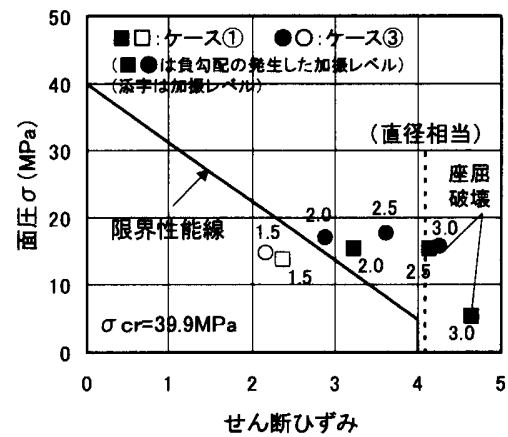

図 8 限界特性との比較（圧縮）

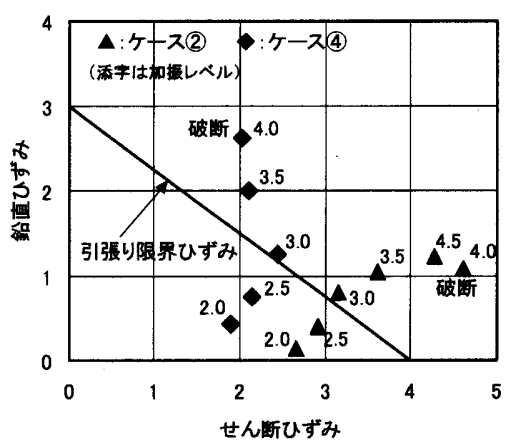

図 9 限界特性との比較（引張り） 
ロと○は水平復元力特性において負勾配が生じたことを表す。図中 の直線は積層ゴムメーカーが提示する圧縮荷重下での限界性能線で、 水平復元力特性における負勾配の発生に応じて規定されたものであ る 8)。これより、実験で初めて負勾配が確認された加振レベル 2.0 $\times \mathrm{L} 2$ が限界性能線に概权対応することが分かる。一方、積層ゴムの 破壊は $3.0 \times \mathrm{L} 2$ で生じているが、 $2.0 \times \mathrm{L} 2$ 以上において負勾配が発 生し、水平変形が直径相当の変形に近づくことを考慮すれば、圧縮 に対する終局加振レベルは $2.5 \times \mathrm{L} 2$ 前後と考えるのが妥当である。 浮き上がり型のケース(2)、(4)について、引張り変形を受ける積層 ゴム B に着目した。図 9 に、 $2.0 \times \mathrm{L} 2$ 以上の加振レベルの最大鈆直 ひずみ（鈶直変形／ゴム総厚）とその時のせん断ひずみをプロット した。直線は積層ゴムの引張り限界ひずみである 9)。これより、両 ケース共に $3.0 \times \mathrm{L} 2$ において引張り限界ひずみを超えている。破断 レベルが引張り限界ひずみを大きく上回った原因については、使用 した積層ゴムが引張り変形能力に優るとされる小型模型であること、 さらに、引張り限界ひずみが直径 $500 \mathrm{~mm}$ 程度の積層ゴムの引張り 試験結果を安全側に評価したものであることが考えられる。積層ゴ ムの終局挙動に及ぼすスケール効果については、実大規模の積層ゴ ムを用いた実験のデータが少なく、十分な検証がなされていないの が現状である 10)。ただし、引張りを受ける積層ゴムの挙動について は、フランジの面外変形によりゴム層の応力分布が不均一になるた め、直径が大きいほどスケール効果が䫓著になることが予想される。 例えば、文献 11)には直径 500〜1200mm の積層ゴムの実験結果よ り、直径が大きくなるにつれて引張り破断ひずみが低下の傾向を示 すことが報告されており、実大規模の積層ゴムの引張り破断ひずみ は、模型のそれよりも小さくなると考えられる。すなわち、実大規 模の建物を想定した場合、引張りに対する終局加振レベルは、本実 験から得られた結果よりもさらに小さくなると考えるべきである。

\section{6. 結論}

積層ゴムで支持した塔状免震建物の終局挙動を解明することを目 的として、縮小免震建物模型を用いた振動台実験を実施した。実験 要因としては、上部構造の塔状比と積首ゴムの形状・面圧を採用し た。塔状比は 4 及び 6 の 2 水準、積層ゴムの形状・面圧は、直径 $90 \mathrm{~mm}$ - 面圧 $7.55 \mathrm{MPa}$ （相対的に小径 - 高面圧）之直径 $110 \mathrm{~mm}$ · 面圧 $5.05 \mathrm{MPa}$ （相対的に大径・低面圧）の 2 水準を設定した。ゴム 総厚は $22 \mathrm{~mm}$ で共通である。これらを組み合わせた 4 ケースについ て、BCJ-L2 波の振幅拡幅波の水平 1 万向入力により積層ゴムが破 壊に至るまで加振した。実験結果より、各要因が終局挙動に与える 影響について検討し、以下の知見を得た。

（1）大入力時における運動パターンは、重鏵の並進的な運動により 両方の積層ゴムに沈み込み変形が生じ重鍾全体が沈み込む「沈み込 み型小重錘の回転的な運動により積層ゴムに引張り変形が生じ重鍾 が浮き上がる「浮き上がり型」、積層ゴムの沈み込み変形と浮き上が り変形が同時に生じる「混在型」に分類された。沈み込み型では、 最終的に水平変形が直径相当の変形を超え、積層ゴムが座屈で破壊 した。浮き上がり型では、積層ゴムに大きな引張り変形が生じ最終 的に積層ゴムが引張り破断した。

（2）大入力時における重鍾の運動パターンは、塔状比（H/B）によ つて定まる剛体の静的浮き上がり限界水平力 $\mathrm{Q}_{\mathrm{up}}(=\mathrm{W} /(\mathrm{H} / \mathrm{B}))$ と
積層ゴムの形状・面圧に関係する免震層水平力 $\mathrm{Q}$ の大小関係に支配 されており、さらに免震層水平変形の積層ゴム直径に対する割合が 関保している。Q $\mathrm{Qup}_{\mathrm{up}}<\mathrm{Q}$ では基本的に浮き上がり型、 $\mathrm{Qup}_{\mathrm{up}}<\mathrm{Q}$ でも水平 変形が積首ゴム直径に近づくと混在型、 $\mathrm{Qup}_{\mathrm{up}}>\mathrm{Q}$ では水平変形が積層 ゴム直径に近づくと沈み込み型となる。

（3）大入力時における積層ゴムの水平力ー水平変形曲線及び鈶直 荷重一鈶直変形曲線は沈み达み型と浮き上がり型で大きく異なって いた。浮き上がり型では、水平力は水平変形だけに、鉛直変形は鉛 直荷重だけに専ら依存する単純な性状を示すが、沈み込み型では、 水平力が水平変形だけでなく鉛直荷重にも、鉛直変形が鉛直荷重だ けでなく水平変形にも強く影響され、複雑な举動を示した。

（4）小径・高面圧のケースでは、加振レベル $2.0 \times \mathrm{L} 2$ で水平復元力 特性に負勾配が初めて確認され、このレベルが圧縮に関する限界性 能線に概ね対応した。最終的には $3.0 \times \mathrm{L} 2$ で座屈破壊に至ったが、 負勾配が発生し水平変形が直径相当の変形に近づくことを考慮すれ ば、本実験における座屈に対する終局加振レベルは $2.5 \times \mathrm{L} 2$ 前後と 考えられる。一方、大径・低面圧のケースは、引張りに関する限界 性能線を大きく超えた $4.0 \times \mathrm{L} 2$ あるいは $4.5 \times \mathrm{L} 2$ で引張り破断した。 これは、引張り変形能力に優るとされる小型積層ゴムを用いたこと が原因と考えられる。よって、実大規模を想定した場合、本実験結 果よりもさらに低い加振レベルで積層ゴムの引張り破断が生じると 考えるべきである。

上記の知見は上部構造を剛体とした実験より導かれたものである が、実免震建物の終局挙動の定性的な評価にも適用可能と考えられ る。一方、終局挙動を予測するためには解析的な検封が必要となる。 大入力時における上部構造の運動パターンが免震層水平力に依存す ることを考慮すれば、今後、積首ゴムの終局時の復元力特性を精度 よく表現するモデルを取り入れた解析手法の構築が必要である。

\section{考文献}

1) 水越熏、八坂厚彦、飯塚真巨、高林勝人：形状係数をパラメータとした積 層ゴムの限界特性実験（その 2 破塥限界特性）、日本建築学会大会学術講演 梗概集 B、pp.601-602、1991.9

2) 日本建築学会編 : 免震構造設計指針、pp.37-38、2001

3) 鬼丸貞友、加藤朝朗、鶴巻静雄、広谷勉、小山実 : FBR 免震型プラントの 構築に関する研究 その 11 免震層の動的破断試験（試験結果の概要）、日 本建築学会大会学術講演梗概集 B、pp.1569-1570、1992.8

4) 猿田正明、田村和夫、菊池優 : 積層ゴムに引張り軸力を生じる免震架構の 振動実験、日本建築学会大会学術講演梗概集 B-2, pp.669-670、1997 年 9 月

5) 久野雅祥、長岛一郎、欄木龍大、富島誠司、飯岛昭治 : 「複合免震構法の高 さ幅比の大きい建物への適用に関する実験的研究 (その 1 振動台実験)」、 日本建築学会大会学術講演梗概集 B-2、pp.603-604、1998 年 9 月。

6) 三山晍史、増田圭司 : 積層ゴムを用いたアスペクト比の高い免震建物の振 動台実験 積層ゴムに生じる引張力とその後の着座による振動性状、日本 建築学会構造系論文集、第 573 号、pp.61-68、2003.11

7) 建設省建築研究所、(財) 日本建築センター：設計用入力地震動作成手法技 術指針（案）、1991

8)（株）ブリチストン：鈶プラグ㨂入型積層ゴム支承技術資料

9) 高山峯夫 : 免震構造用天然ゴム系積層ゴムアイソレータの限界性能、日本 建築学会技術報告集、第 1 号、pp.160-165、1995.12

10) 日本免震構造協会技術委員会実験 WG : 積層ゴムのスケール効果確認試験 結果の報告、MENSHIN、No.35、pp.22-37、2002.2

11)村松佳孝、西川一郎、川端一三、高山正春、木村雄一：大サイズ天然ゴム 系積層ゴムアイソレータの引張特性、日本建築学会技術報告集第 12 号、 pp.53.56、2001.1

12) 14)竹中康雄、飯塚真巨、二村有則、吉川和秀、高岡栄治 : 塔状免震建 物の終局举動に関する振動台実験（その 1) 〜 (その 3)、日本建築学会大 会学術講演梗概集 B-2，pp.783-788，1999.9

15) 17)飯塚真巨、二村有則、竹中康雄、吉川和秀、高岡栄治 : 塔状免震建 物の終局挙動に関する振動台実験（その 4) 〜 (その6)、日本建築学会大 会学術講演梗概集 B-2、pp.645-650、2000.9 